
Revista
Brasileira
de Enfermagem
REBEn
THEMATIC EDITION:
GOOD PRACTICES: FUNDAMENTALS OF
CARE IN GERONTOLOGICAL NURSING

RESEARCH

\title{
Effects of a Health Education program on cognition, mood and functional capacity
}

\author{
Efeitos de um programa de Educação em Saúde na cognição, humor e capacidade funcional \\ El Efecto de la Educación para la Salud sobre la cognición, humor y capacidad funcional
}

\section{Juliane Cristine Dias', Isabela Azevedo Rodrigues', Francine Golghetto Casemiro", Diana Quirino Monteiro", Bruna Moretti Luchesi", Marcos Hortes Nisihara Chagas', Paula Costa Castro', Sofia Cristina Iost Pavarini',"I, Aline Cristina Martins Gratão,,II}

\author{
' Universidade Federal de São Carlos, Center for Biological and Health Sciences, Department of Gerontology. \\ São Carlos, São Paulo, Brazil. \\ "Universidade Federal de São Carlos, Postgraduate Program in Nursing. São Carlos, São Paulo, Brazil.
}

\begin{abstract}
How to cite this article:
Dias JC, Rodrigues IA, Casemiro FG, Monteiro DQ, Luchesi BM, Chagas MHN, et al. Effects of a Health Education program on cognition, mood and functional capacity. Rev Bras Enferm [Internet]. 2017;70(4):814-21. [Thematic Edition "Good Practices: Fundamentals of care in Gerontological Nursing"] DOI: http://dx.doi.org/10.1590/0034-7167-2016-0638
\end{abstract}

Submission: 04-12-2016

Approval: 04-04-2017

\section{ABSTRACT}

Objective: Assess the effect of a Health Education (HE) program on cognition, mood and functional capacity of participants in a University of The Third Age (U3A). Method: Controlled clinical trial. The HE Program consisted of 10 sessions with group dynamics, including orientations on disease prevention and cognitive stimulation exercises, lasting four months. Intervention Group (IG) $n=13$; and Control Group (CG) $n=15$. All were assessed at the start and end of the study, using Addenbrook's Cognitive Examination-Revised (ACE-R), Beck Depression and Anxiety Inventory (BDI/BAI) and Functional Independence Measure (FIM). Results: Significant improvements were observed for the IG when comparing the total ACE-R score $(p=0.001)$ and memory domain $(p=0.011)$ before and after the intervention. For the CG, improvement was found in the memory domain only $(p=0.027)$. Conclusion: a HE intervention program benefits the improvement in cognitive performance, particularly the memory of adults and active elderly who participated in a U3A.

Descriptors: Aged; Health Education; Cognition; Geriatric Nursing; Activities of Daily Living.

\section{RESUMO}

Objetivo: Avaliar o efeito de um programa de Educação em Saúde (ES) na cognição, humor e capacidade funcional de participantes de uma Universidade Aberta da Terceira Idade (UATI). Método: Ensaio clínico controlado. O programa de ES consistiu de 10 sessões com dinâmicas de grupo, incluindo orientações sobre prevenção de doenças e exercícios de estimulação cognitiva, durante quatro meses. Grupo Intervenção (IG) $n=13$; e Grupo Controle (CG) $n=15$. Todos foram avaliados no início e no final do estudo, utilizandose o Addenbrook's Cognitive Examination-Revised (ACE-R), o Inventário de Depressão e Ansiedade Beck (BDI/BAI) e a Medida de Independência Funcional (FIM). Resultados: observou-se melhora significativa no IG ao comparar o escore do ACE-R $(p=0,001)$ e do domínio memória $(p=0,011)$ antes e após a intervenção. No CG, houve melhora apenas no domínio memória $(p=0,027)$. Conclusão: um programa de ES beneficia a melhoria do desempenho cognitivo, particularmente a memória de participantes ativos de uma UATI. Descritores: Idoso; Educação em Saúde; Cognição; Enfermagem Geriátrica; Atividades Cotidianas.

\section{RESUMEN}

Objetivo: Evaluar los efectos de la Educación para la Salud (ES) en la cognición, humor y capacidad funcional de participantes de una Universidad Abierta de la Tercera Edad. Método: Se trata de un ensayo clínico controlado. El Programa de Educación para la Salud consistió en 10 sesiones con dinámicas de grupo, con orientaciones sobre prevención de enfermedades y ejercicios de estimulación cognitiva, con duración de 4 meses. Participaron 13 personas en el grupo de intervención (Gl) y 15 en el grupo control (GC). Todos fueron evaluados al inicio y al término del estudio con los instrumentos Addenbrook's Cognitive Examination-Revised (ACE-R), Inventario de Depresión y Ansiedad de Beck (BDI/BAI) y con la Medida de la Independencia Funcional (FIM). Resultados: 
se observaron mejoras significativas en el Gl cuando se compararon los resultados del ACE-R ( $p=0,001)$ y el dominio de la memoria $(p=0,001)$ antes y después de la intervención. Para el GC fue encontrada una mejora significativa solamente en el dominio de la memoria $(p=0.027)$. Conclusión: Los resultados sugieren que la intervención educativa estudiada tiene efecto beneficioso en el desempeño cognitivo de los participantes de la Universidad Abierta de la Tercera Edad.

Descriptores: Adulto Mayor; Educación para la Salud; Cognición; Enfermería Geriátrica; Actividades de la Vida Diaria.

\section{CORRESPONDING AUTHOR Aline Cristina Martins Gratão Email: aline-gratao@hotmail.com}

\section{INTRODUCTION}

The number of older people is increasing very fast in the world, as a result of high the birth rates in the past, and the enhanced life expectation. In 2013, the elderly population was 841 million worldwide. This number is growing fast, especially in the less developed regions, where it will triple by 2015, reaching 1.6 billion, in comparison with 554 million in 2013 and 108 million in 1950 (1).

Besides the demographic transition process, the population has gone through epidemiological transformations. The elderly are incorporated into the society, mostly bearers of non-transmissible chronic conditions and some of functional disabilities, requiring further attention from society (2).

The life course needs to be more individualized and flexible, with a specific focus on resilience, through four pillars: health, participation, security and lifelong learning. The last pillar postulates that the learning experiences need to be multiplied over the life course, focusing education not only targeted to work-related knowledge, but also to technology, finances, and health aspects ${ }^{(3)}$.

Gerontology, being the science and practice of the assistance to and management of elderly care and ageing process, can and should work not only to avoid or retard illnesses, but also privilege healthy aging, which demands the maintenance and strengthening of the elderly physical and mental functions, as well as his social engagement through significant productive activities and interpersonal relationships ${ }^{(4)}$. Gerontological nursing may develop actions in different fields like education, practice, advisory, planning and coordination of services. These professionals need to respect the subjectivity and individuality of the older adults ${ }^{(5)}$.

Examples of actions in that sense are strategies like health education, widely implemented in contexts like universities open to the elderly, granting favorable conditions to improve anxiety and depression symptoms, besides enhancing individuals' cognitive and functional ability ${ }^{(6-7)}$.

Health Education (HE) is an educational process of building knowledge in health that aims a thematic appropriation by the population, and a set of practices that contribute to increase the autonomy of the people ${ }^{(8)}$. However, the educational actions still follow a traditional model, characterized by vertical interventions that do not consider the reality of the people and are not designed to stablish a relationship between the health team and the population ${ }^{(6)}$.

The cognitive ability is a set of functions that allows individuals to interact with the world. Its main functions are: memory, executive function, language, visuospatial function, gnosis and praxis. The cognitive function can be compromised in different ways, ranging from alterations associated with aging (senescence) to mild cognitive commitment and dementias, which can be identified through cognitive and functional assessment instruments ${ }^{(9)}$.

Associated with cognitive decline, another important factor to be taken into account is the presence of depressive symptoms. According to the World Health Organization, it is estimated that 350 million people around the world present depressive symptoms. Depression is a chronic condition with severe symptoms and, if left undiagnosed and treated, it can turn into a severe health condition, impair the daily activities and even lead to death ${ }^{(10)}$. In the elderly, the fear that something bad may happen, health issues, financial problems and fear of abandonment can cause anguish, anxiety and concern and, consequently, aggravate the depressive symptoms ${ }^{(11)}$.

Anxiety can manifest itself through excessive, unreal and generalized concerns about events or activities and, in the elderly, it can be related with the limitations and transformations in old age, which are often considered threatening events. A person with anxiety presents mental symptoms like insomnia, tension, anguish, irritability, cognitive decline, as well as physical symptoms like tachycardia, dizziness, headache, muscle aches, tingling and sweating ${ }^{(12)}$.

Educational actions should be continuing, working as a fundamental strategy to the health promotion, and thus permitting the individual's integration in society, turning into the main agent of his health-disease-care process, improving his quality of life ${ }^{(13)}$. With a view to the efficacy of educational actions as an intervention strategy, the professional needs to adopt a more sensitive posture in order to consider possible demands from patients, through a dialogue that allows the professional to identify these individuals' doubts, knowledge, beliefs, needs and inquiries ${ }^{(6,13-14)}$.

Considering that: the educational actions are mostly developed in a traditional way; that the evaluation of the impact of HE programs usually is in terms quality of life, autonomy, citizenship, participation and social interaction ${ }^{(6,13-14)}$; and that this interventions do not consider the possible improvements on cognition, mood and functional ability; there is a lack of knowledge concerning the impact of a participative HE program on this variables.

\section{OBJECTIVE}

This study aimed to verify the effects of a HE program on cognition, mood and functional ability of adults and active elderly who participated in the continuing education program of a University of the Third Age (U3A), through pre and postintervention assessments. 


\section{METHOD}

\section{Ethical aspects}

The study was approved by the Federal University of São Carlos Ethics Committee and the program only started after the participants had given their written, informed consent.

\section{Design, study site and period}

A controlled clinical trial was undertaken, involving a waiting list and pre and post-intervention. It was developed in a U3A in Brazil. This U3A has existed for 20 years and is affiliated with a Foundation destined to adult and elderly education. The Foundation develops a continuing education program for middle-aged and old-aged people in health, culture, sports, leisure, citizenship and work. In 2013, the baseline population of the U3A consisted of 458 participants, mostly women $(92 \%)$, with a mean age of $63.3 \pm 10.4$ years, ranging from 40 to 89 years of age. The majority is middle-class and the educational level varies (from illiterate to post-graduates) (7). It was developed between February and August 2015.

\section{Population or sample: inclusion and exclusion criteria}

The baseline population for the sample of subjects in the trial and control groups consisted of the participants in the U3A. The subjects were selected after the dissemination of the $\mathrm{HE}$ Gerontology Program, when 40 people were interested. The power reached at a significance level of 0.05 and a minimally detectable difference of means (Addenbrook's Cognitive Examination-Revised - ACE-R) observed was $72.7 \%$. The first group of interested people $(n=20)$ was enrolled to take part in the workshop, and the second group was put on a waiting list to await a new edition of the workshop. It is noteworthy that the group on the waiting list continued to attend other U3A activities.

The inclusion criteria were subjects aged 50 years or older, proven through personal documents valid across the Brazilian territory and enrolled in the U3A. And the exclusion criteria were auditory or visual disabilities that hindered communication and application of the tests; presence of cognitive deficit, measured using the ACE- $\mathrm{R}^{(15-16)}$, with a score inferior to 78 point; and participation in the entire program (including the initial and final assessments).

According to the inclusion and exclusion criteria, seven participants were excluded from the Intervention Group (IG), because they were younger than 50 years $(n=2)$, because they dropped out $(n=2)$ and because their cognitive performance was lower than expected $(n=3)$. Five participants were excluded from the Control Group (CG) because they were younger than 50 years $(n=2)$, because they did not participate in the final assessment $(n=2)$ and because their cognitive performance was lower than expected $(n=1)$. Thus, 28 subjects participated in the study, distributed in two groups: IG with 13 subjects who participated in the HE program and CG with 15 subjects who did not participate in the program (waiting list). A paired t-test power of $99 \%$ was calculated for the final sample, with an error margin of 0.05 .
In Figure 1, the participants' flowchart can be observed.

\section{Study protocol}

An interview was held with the participants and an assessment protocol was applied, consisting of: a sociodemographic profile questionnaire (sex, age, education, marital status). In addition, a pre and post-intervention assessment took place, using the following instruments:

ACE- $R$ is a brief battery of cognitive tests that was developed by researchers from the Cognitive Neurology Service of Cambridge University, United Kingdom, in 2000. The ACER-R was adapted to Brazilian Portuguese and validated ${ }^{(15)}$. This tool tests five cognitive domains separately. The maximum score is 100 , allocated as follows: Orientation and attention (18); memory (35); verbal fluency (14); language (28); and visuo-spatial skills (5). The scores relative to each of the six cognitive domains can be computed separately, and their sum corresponds to the participant's total score on the ACE-R. Within this sum there are 30 points referring to the MMSE score. A recent study confirmed that the Brazilian version of the ACE-R maintains high accuracy in identifying Alzheimer's disease, when the cutoff point is set at $78^{(16)}$.

To screen for anxiety symptoms, the Beck Anxiety Inventory $(\mathrm{BAI})$, validated in Brazil ${ }^{(17)}$, which consists of a list of 21 common anxiety symptoms, with four alternatives each, in increasing order of anxiety level. The cut-off score corresponds to: 0-10 points, minimal symptoms or absence of anxiety; 11-19, mild; 20-30, moderate; and 31-63, severe. Anxiety is considered clinically important as from the mild level ${ }^{(17-18)}$.

The Beck Depression Inventory (BDI) is a symptomatic scale of depression. It consists of 21 multiple-choice questions with four alternatives, each scored on a scale from zero to three points. The sum of the scores results in a total score that indicates the intensity of the depression, ranging between the levels: 0 to 9 minimum symptoms or absence of symptom, 10 to 18 mild symptoms, 19 to 29 moderate symptoms and 30 to 63 points for symptoms of severe depression ${ }^{(17-18)}$. 
The Functional Independence Measure - FIM is a tool to assess the disability of patients with functional restrictions of different origins and has been validated for the Brazilian context ${ }^{(19)}$. Its main objective is to quantitatively assess the care burden demanded by an individual to accomplish a range of motor and cognitive tasks of daily living. Its cut-off scores are: Complete dependence (total assistance) $=18$ points; Maximum dependence (assistance of up to $75 \%$ to accomplish the task) and Moderate dependence (assistance of up to $50 \%$ to accomplish the task) $=19-60$ points; Minimal dependence (assistance of up to $25 \%$ to accomplish the task) and Supervision, stimulus or setup $=61-103$; Modified Independence and Complete Independence $=104-126$ points.

Concerning the intervention, it started with the survey of the themes the participants were interested in discussing during the educational action. The thematic classes were elaborated, besides the dynamics chosen, based on the book "Dinâmicas para idosos: 125 jogos e brincadeiras adaptados" (Dynamics for elderly: 125 adapted games)(20). After the integration and participation of all, further information was provided on how the meetings would take place. On a sheet of paper, each participant wrote down two themes (s) he would like to be discussed, totaling 28 different themes, as some themes were related or repeated. The themes chosen included: Cognition; Isolation; Solitude; Osteoporosis; Heart; Alzheimer; "Is depression part of forgetting?"; Health orientation; "Why are we losing our memory over the years?"; "Should the elderly be treated as an elderly or as a normal person?"; Social support; Memory; Dermatitis - psoriasis (Difference). Thus, the ten most mentioned themes were listed, which were discussed weekly. Each session took 60 minutes, through educational and dynamic actions, totaling 10 meetings. It should be highlighted that the CG was invited to and participated in the final meeting. In Chart 1, the activities performed have been illustrated.

\section{Statistical Analysis}

In the data analysis, the mean scores for the variables cognition (ACE-R and MMSE) and domains of the ACE-R, BDI, BAI and FIM were compared and analyzed for the baseline using Student's t-test or Mann-Whitney's test for independent samples, according to the distribution. The categorical variables sex, education, marital status and occupational situation were compared and analyzed using Fisher's exact test and the $X^{2}$ test.

To compare the IG and CG, the variation, i.e. post-intervention measure minus pre-invention measure, was calculated for the instruments applied. Next, the Mann-Whitney test was applied to check for intergroup differences. The intragroup differences were determined using Student's t-test for paired samples or the Mann-Whitney test. The distribution of the variables measures was considered as parametric or non-parametric, according to the Kolmogorov-Smirnov test. The data analysis was developed in the software Statistical Package for Social Science (SPSS), version 20.0. P-values $<0.05$ were considered statistically significant.

\section{RESULTS}

In Chart 1, the sociodemographic and clinical characteristics of the two groups have been described. No intergroup differences were found at baseline for the variables studied, except for the total BAI score, which was higher for the IG. Therefore, it is understandable that the groups were equivalent for most variables, except for anxiety symptoms.

As regards the variation (difference between post and preintervention measures) in the total score of the instruments used, a statistically significant difference was found for the ACE-R $(p=0.019)$ and BDI $(p=0.010)$ scores. In Table 1, the intragroup differences have been described for the ACE-R and its domains, and the BDI. No differences were found for the other variables (BAI, FIM, MMSE) and they have not been displayed in the table.

Chart 1 - Themes addressed during educational sessions, São Carlos, São Paulo, Brazil, 2015

\begin{tabular}{|c|c|c|l|l|}
\hline Session & IG & CG & \multicolumn{1}{|l|}{ Theme } \\
\hline $\mathbf{0 1}$ & $\mathrm{X}$ & - & Theme 1: What is Gerontology? Dynamics: "Self-qualification" \\
\hline $\mathbf{0 2}$ & $\mathrm{X}$ & - & Theme 2: Aging of the Brazilian population: Solitude in old age? The importance of social support. Dynamics: "Affective Badges" \\
\hline $\mathbf{0 3}$ & $\mathrm{X}$ & - & Theme 3: Aging of the cardiac system. Dynamics: "Verification of Blood Pressure" and "Framingham Score" \\
\hline $\mathbf{0 4}$ & $\mathrm{X}$ & - & Theme 4: Mental health (Depression/Anxiety). Dynamics: "Drawings to illustrate the theme" \\
\hline $\mathbf{0 5}$ & $\mathrm{X}$ & - & Theme 5: Cognitive aging (Memory/Forgetting/Alzheimer). Dynamics: "That reminds me" \\
\hline $\mathbf{0 6}$ & $\mathrm{X}$ & - & Theme 6: Exercises for the memory (contact with games). Dynamics: Mind gym games" and the strategy "Think well" \\
\hline $\mathbf{0 7}$ & $\mathrm{X}$ & - & Theme 7: Musculoskeletal aging. Dynamics "Electric Current Wheel" \\
\hline $\mathbf{0 8}$ & $\mathrm{x}$ & - & Theme 8: Integumentary aging/Dermatitis/Psoriasis. Dynamics: "Talent Wheel" \\
\hline $\mathbf{0 9}$ & $\mathrm{x}$ & - & Theme 9: Food: Supplementation/Vitamins. Dynamics: “Gluten and Lactose Free Recipes" \\
\hline $\mathbf{1 0}$ & $\mathrm{x}$ & $\mathrm{x}$ & Theme 10: Physical Activity and Closure of activities. Dynamics with music and breakfast with fruit \\
\hline
\end{tabular}

Note: IG - Intervention Group; CG - Control Group 
Higher scores can be identified when comparing the pre and post-intervention in the total ACE-R scores $(p=0.001)$ and memory domain $(p=0.011)$. For the $C G$, only the memory domain improved, as demonstrated in Table 2.

Table 1 - General characteristics of participants in intervention and control groups, São Carlos, São Paulo, Brazil, 2015

\begin{tabular}{|c|c|c|c|}
\hline \multirow{2}{*}{ Variables } & \multicolumn{2}{|c|}{ Group } & \multirow{2}{*}{$\underset{\text { value }}{p}$} \\
\hline & IG $(n=13)$ & $C G(n-=15)$ & \\
\hline Mean age \pm sd & $66.4 \pm 8.4$ & $70.0 \pm 11.5$ & 0.357 \\
\hline \multicolumn{4}{|l|}{ Sex } \\
\hline Female n $(\%)$ & $10(76.9)$ & $15(100)$ & 0.087 \\
\hline Male n (\%) & $03(23.1)$ & - & \\
\hline \multicolumn{4}{|l|}{ Marital status n (\%) } \\
\hline With partner & $08(61.5)$ & $09(60.0)$ & 1.000 \\
\hline No partner & $05(38.5)$ & $06(40.0)$ & \\
\hline \multicolumn{4}{|l|}{ Education $\mathrm{n}(\%)$} \\
\hline $1-4$ years education $n(\%)$ & $02(15.4)$ & $01(6.7)$ & 0.336 \\
\hline $5-8$ years education $n(\%)$ & $04(30.8)$ & $02(13.3)$ & \\
\hline 9 years or more $\mathrm{n}(\%)$ & $07(53.8)$ & $12(80.0)$ & \\
\hline ACE-R mean \pm sd & $85.6+5.1$ & $88.7+5.1$ & 0.119 \\
\hline MMSE mean \pm sd & $27.5+1.9$ & $27.8+1.7$ & 0.623 \\
\hline BDI mean $\pm \mathrm{sd}^{*}$ & $5.1 \pm 3.8$ & $5.4 \pm 3.6$ & 0.892 \\
\hline $\mathrm{BAI}$ mean $\pm \mathrm{sd}$ & $6.0 \pm 4.6$ & $1.6 \pm 2.0$ & 0.004 \\
\hline FIM mean \pm sd ${ }^{*}$ & $124.5 \pm 2.4$ & $125.1 \pm 1.0$ & 0.964 \\
\hline
\end{tabular}

Note: IG: Intervention Group; CG: Control Group; sd: Standard Deviation; ACER: Addenbrook's Cognitive Examination-Revised; MMSE: Mini Mental State Examination; BDI: Beck Depression Inventory; BAI: Beck Anxiety Inventory; FIM: Functional Independence Measure; *Non-parametric distribution.

\section{DISCUSSION}

In this study, which evaluated the effects on cognition, mood and functional ability of adults and active elderly who participated in a continuing HE program of a U3A, we observed that the HE was able to improve the scores for general cognitive, specially the memory domain of the ACE-R.

Memory is one of the essential cognitive functions of human beings, as it is fundamental in the teaching-learning process and in individuals' definition of their identity. Without memory, the process of accumulating and transmitting experiences to other people would not be possible, which permit the socialization of the human species $^{(21)}$.

For the elderly, in view of the fact that, in this phase of life, cognitive losses can be more present, the intensification of the activity-based stimuli, to make the memory remain operative, minimize these losses, even if genetic factors are relevant to understand each person's particular differences ${ }^{(22)}$. The research participants, mostly elderly, with a clear improvement in the memory domain, prove that a good HE strategy based on dynamics can be efficient to stimulate the preservation and improvement of cognitive performance.

A recent study conducted in Kuala Lumpur, Singapore, determined that a 12-month educational intervention on nutritional, lifestyle, and cognitive function of elderly individuals with mild cognitive impairment $(\mathrm{MCl})$ significantly improved nutritional status, knowledge and had a positive effect on cognitive performance ${ }^{(23)}$. Another investigation evaluated a cognitive therapy conducted by caregivers of people with Alzheimer's Disease at home. They observed an improvement on cognition after three months, indicating that this type of interventions can be a technology of nursing care ${ }^{(24)}$.

Cognition should be measured not only through tests that diagnose individuals with possible dementia. Other domains, such as visual-spatial perception, memory, attention, information processing, reasoning and problem-solving ability should also be considered ${ }^{(25-26)}$. A study aimed at investigating the

Table 2 - Distribution of means and standard deviations for the variables Addenbrook's Cognitive Examination-Revised and its domains and Beck Depression Inventory, São Carlos, São Paulo, Brazil, 2015

\begin{tabular}{|c|c|c|c|c|c|c|}
\hline \multirow{2}{*}{$\begin{array}{l}\text { Variables } \\
\text { mean } \pm \text { sd }\end{array}$} & \multicolumn{3}{|c|}{ IG } & \multicolumn{3}{|c|}{ CG } \\
\hline & Before & After & $p$ value $^{*}$ & Before & After & $p$ value ${ }^{*}$ \\
\hline ACE-R & $85.62 \pm 5.09$ & $92.15 \pm 4.88$ & 0.001 & $88.73 \pm 5.12$ & $90.60 \pm 5.33$ & 0.091 \\
\hline Orientation/Attention* & $16.85 \pm 1.51$ & $17.23 \pm 1.36$ & 0.337 & $17.07 \pm 1.03$ & $17.33 \pm 0.98$ & 0.194 \\
\hline Memory* & $17.23 \pm 4.02$ & $21.46 \pm 3.23$ & 0.011 & $18.60 \pm 2.97$ & $19.00 \pm 2.90$ & 0.027 \\
\hline Verbal Fluency* & $13.23 \pm 1.01$ & $13.69 \pm 1.11$ & 0.202 & $12.53 \pm 1.36$ & $12.53 \pm 1.64$ & 1.000 \\
\hline Language* & $24.69 \pm 1.55$ & $24.92 \pm 0.95$ & 0.558 & $25.07 \pm 1.16$ & $25.20 \pm 1.01$ & 0.593 \\
\hline Visual-Spatial* & $13.85 \pm 2.30$ & $15.00 \pm 1.68$ & 0.063 & $15.00 \pm 1.13$ & $15.13 \pm 1.13$ & 0.705 \\
\hline BDI* & $5.38 \pm 3.60$ & $3.38 \pm 4.45$ & 0.065 & $5.07 \pm 3.85$ & $5.60 \pm 4.66$ & 0.601 \\
\hline
\end{tabular}

Note: IG: Intervention Group; CG: Control Group; sd: Standard Deviation; ACE-R: Addenbrook's Cognitive Examination-Revised; BDI: Beck Depression Inventory; * Non-parametric distribution. 
effects of a digital inclusion program in the cognitive performance of older individuals who participated in a computer learning workshop named "Idosos On-Line" (Elderly Online). The workshop included fifteen 120-min lessons and the topic of each lesson was always associated with health-related issues and the aging process. Forty-two aged individuals participated in the research study: 22 completed the computer training workshop and 20 constituted the control group. The results showed that the experimental group's cognitive performance significantly improved after the program, particularly in the language and memory domains ${ }^{(27)}$.

Thus, the importance of activities like cognitive interventions is understood for this population, as exemplified in this study through attention, memorization and learning actions in group discussions, by means of dynamics and socialization. Added to this, is the fact that the present study is not an exclusively cognitive intervention, but a HE program, and it was able to improve the memory domain and the general cognitive ability of the participants. Other authors sustain this hypothesis, affirming that engagement in social, physical or intellectual activities is associated with the increase in or maintenance of cognitive ability ${ }^{(28)}$.

To be healthy in old age, continuous learning is needed. Gerontology offers countless arguments in favor of education, promotion of integration and elderly people's participation in social life. Among these, the new learning health education promotes is highlighted as an important resource to maintain the elderly people's functionality, flexibility, preservation and improvement of cognitive performance, quality of life and adaptation possibilities ${ }^{(14,28-29)}$. These conditions are associated with the concept of successful old age. Educational opportunities are considered important antecedents of evolving gains in old age, because it is believed that they intensify the social contacts, experience exchange and knowledge, as well as personal development. $\mathrm{HE}$ groups represent an important way to associate scientific, professional and popular knowledge, and beyond that, provides opportunities to create a new social network ${ }^{(30)}$.

Besides the improvement in cognitive ability, the statistics appointed no significant results regarding depressive symptoms. However, the IG showed a reduction in the score (from 5.38 before intervention to 3.38 after intervention) and the CG an increased score (from 5.07 to 5.60).

Depressed patients present lowering of mood, reduction of energy and decrease in activity. Alterations are found in the ability to experience pleasure, loss of interest, reduced ability to concentrate, generally associated with important fatigue, even after minimal effort. As observed, the most common symptoms are sleep problems and reduced appetite. There is almost always a reduction in self-esteem, self-confidence and, frequently, ideas of guilt and/or uselessness, even in mild forms ${ }^{(31)}$.

Depression involves a series of commitments in a person's functioning. A study developed in Brazil investigated the social skills, social support, quality of life and depression of elderly people who took part in a U3A, originating in family contexts and asylums. They found that the elderly from the asylum group presented significantly higher levels of depression. The authors concluded that depressive symptoms are associated with worse social functioning and quality of life $\mathrm{f}^{(32)}$.
This leads to the understanding that participating in educational meetings can minimize these factors predisposing to depression, which in the present study occurred for the IG.

However, in another study in this area, it is appointed that cognitive loss represents a characteristic of depression and that depressed individuals tend to present worse psychosocial functioning $^{(33)}$. Considering that there were a reduction in the depressive symptoms score, this could help to explain the gains in the general cognitive ability and memory domain presented by the IG.

The participants in the IG demonstrated their interest in the HE Program because they perceived the possibility not only to revert certain habits, but also to take forward new information. The orientations and discussions that took place in this space resulted in growth and transformation and, for many, what is experienced during the meetings is not only gratifying, but also socialized with other people, becoming part of the dimension of daily living, causing the feeling of utility and satisfaction, which greatly contributed to the decrease in depressive symptoms in this group.

\section{Study limitations}

Some limitations in this study were the small sample size and the non-possibility of randomization, which made the data analysis more difficult, as many conditions related to the subjects' life, as well as the participation of the IG and the CG in other activities in the U3A, may have exerted strong influence on the research findings. Regarding the outcome measures, an objective assessment of participants' satisfaction and motivation should have been included.

\section{Contributions to public health}

The strengths of this study are as follows. First, studies with this type of design remain scarce and the importance of implementing strategies appropriately and systematically, including before-and-after assessments of the intervention with a CG, permits understanding the true impact on the participants' health. Second, this study permitted the training of the gerontology health team for this type of education strategy, working as a technology of health care. Third, as far as we know, there are not many studies looking into the strategy of educational sessions combined with dynamic actions specific for elderly public.

The Brazilian Elderly Health Policies acknowledges the importance of training for comprehensive care, appointing that it should make it possible to systemize care, privileging tasks related to health promotion, disability prevention and maintenance of participation of community-based adults and elderly ${ }^{(34)}$. The World Health Organization says that the Healthy Ageing trajectory of each person is different, and is influenced by the choices and interventions that occur in different points of the life ${ }^{(35)}$. A HE Program that focuses on health promotion can change the trajectory of the older adults.

The same intervention protocol presented here should be used in future research and practical interventions. They maybe comprise a larger number of lessons and involve more participants. The HE program should also be developed in different settings related to health promotion like Family Health Units, and be planned by multidisciplinary teams. This kind 
of intervention that showed an effect on cognition can work as an important tool to promote a health ageing in the context of population ageing.

\section{CONCLUSION}

These research results suggest that a HE intervention program benefits the improvement in cognitive performance, particularly the memory of adults and active elderly who participated in a U3A. However, we should note that the adults that do not participated in the intervention, but participated in other U3A activities, also had an improvement in the memory domain. These results do not appear to be of such a value as to recommend the widespread use of the HE program, although they may indicate interesting research paths.

\section{FUNDING}

This work was supported by Fundação de Amparo à Pesquisa do Estado de São Paulo (FAPESP - Grant number 2014/18829-4).

\section{REFERENCES}

1. United Nations. World Population Ageing 2013[Internet]. New York, NY: United Nations: Department of Economic and Social Affairs, Population Division, 2013 [cited 2016 Jul 12]. Available from: http://www.un.org/en/development/desa/population/ publications/pdf/ageing/WorldPopulationAgeing2013.pdf

2. Veras R. Envelhecimento populacional contemporâneo: demandas, desafios e inovações. Rev Saúde Pública [Internet]. 2009 [cited 2016 Jul 12];43(3):548-54. Available from: http://www.scielosp.org/pdf/rsp/v43n3/224.pdf

3. International Longevity Center Brazil. Active Ageing: A Policy Framework in Response to the Longevity Revolution. [Internet]. Rio de Janeiro, RJ, Brazil, 2015 [cited 2016 Oct 20]. Available from: http://ilcbrazil.org/wp-content/uploads/2016/02/Active-Ageing-A-Policy-Framework-ILCBrazil_web.pdf

4. Silva PFC, Faria SM, Carriço IC, Casemiro FG, Costa FN, Castro PC. O papel do bacharel em Gerontologia na Universidade da Terceira Idade: um relato de experiência. Kairós Gerontol [Internet]. 2015 [cited 2016 Jul 12];18(19):149-65. Available from: http://revistas.pucsp.br/index.php/kairos/article/view/27265/19299

5. Santos RRAS, Aquino DMC, Coutinho NPS, Laged JS, Corrêa RGC. Gerontologia e a arte do cuidar em enfermagem: revisão integrativa da literatura. Rev Pesq Saúde [Internet]. 2013 [cited 2016 Jul 12];14(2):118-23. Available from: http://www. periodicoseletronicos.ufma.br/index.php/revistahuufma/article/view/2306/392

6. Menezes Júnior JE, Queiroz JCD, Fernandes SCDA, Oliveira LCD, Coelho SQF. Educação em Saúde como estratégia para melhoria da qualidade de vida dos usuários hipertensos. Rev Rene [Internet]. 2011 [cited 2016 Jul 12];12:1045-51. Available from: http:// www.revistarene.ufc.br/vol12n4_esp_html_site/a21v12espn4.html

7. Castro PC, Aciole GG, Driusso P, Oishi J. Papel do fisioterapeuta na Universidade Aberta da Terceira Idade de São Carlos. Estud Interdiscipl Envelhec [Internet]. 2014 [cited 2016 Jul 12];19(1):287-305. Available from: http://www.seer.ufrgs.br/index.php/ RevEnvelhecer/article/view/35267/31015

8. Brasil. Ministério da Saúde. Secretaria-Executiva. Secretaria de Gestão do Trabalho e da Educação na Saúde. Glossário temático: gestão do trabalho e da educação na saúde [Internet]. 2. ed. Brasília: MS; 2012. [cited 2017 Mar 22]. Available from: http://lbvsms. saude.gov.br/bvs/publicacoes/glossario_gestao_trabalho_2ed.pdf

9. Chételat G, Landeau B, Salmon E, Yakushev I, Bahri MA, Mézenge F, Perrotin A et al.. Relationships between brain metabolism decrease in normal aging and changes in structural functional connectivity. Neuroimage [Internet]. 2013 [cited 2016 Jul 12];76:16777. Available from: http://dx.doi.org/10.1016/j.neuroimage.2013.03.009

10. World Health Organization. Fact Sheet no 369. Depression [Internet]. 2012 [cited 2015 Sep 15]. Available from: http://www.who. int/mediacentre/factsheets/fs369/en/

11. Chaves ÉCL, Paulino CFE, Souza VHS, Mesquita AC, Carvalho FS, Nogueira DA. Quality of life, depressive symptoms and religiosity in elderly adults: a cross-sectional study. Texto Contexto Enferm [Internet]. 2014 [cited 2016 Jul 12];23(3):648-55. Available from: http://www.scielo.br/pdf/tce/v23n3/0104-0707-tce-23-03-00648.pdf

12. Frank MHR. Depressão, ansiedade, outros distúrbios afetivos e suicídio. In: Freitas EV, Py L(Ed). Tratado de geriatria e gerontologia. Rio de Janeiro: Ed. Guanabara Koogan, 2011. p.376-87.

13. Silva FM da, Budó MLD, Girardon-Perlini NMO, Garcia RPG, Sehnem GD, Silva DC da. Contribuições de grupos de educação em saúde para o saber de pessoas com hipertensão. Rev Bras Enferm [Internet]. 2014 [cited 2016 Dec 05];67(3):347-53. Available from: http://www.scielo.br/pdf/reben/v67n3/0034-7167-reben-67-03-0347.pdf

14. Gazzinelli MF, Souza V, Fonseca RMGS, Fernandes MM, Carneiro ACLL, Godinho LK. Educational group practices in primary care: interaction between professionals, users and knowledge. Rev Esc Enferm USP [Internet]. 2015 [cited 2016 Jul 12];49(2):282-89. Available from: http://www.scielo.br/pdf/reeusp/v49n2/0080-6234-reeusp-49-02-0284.pdf

15. Carvalho VA, Caramelli P. Brazilian adaptation of the Addenbrooke's cognitive examination-revised (ACE-R). Dement Neuropsychol [Internet]. São Paulo, 2007 [cited 2016 Jul 12];1(2):212-16. Available from: http://www.demneuropsy.com.br/detalhe_artigo. asp?id $=121$ 
16. Carvalho VA, Barbosa MT, Caramelli P. Brazilian version of Addenbrooke's Cognitive Examination in the diagnosis of mild Alzheimer Disease. Cog Behav Neurol [Internet]. 2010 [cited 2016 Jul 12];23(1):8-13. Available from: http://dx.doi.org/10.1097/ WNN.0b013e3181c5e2e5

17. Cunha JA. Manual da versão em português das Escalas Beck. São Paulo: Casa do Psicólogo; 2001.

18. Beck AT, Ward CH, Mendelson M, Mock J, Erbaugh J. Inventory for Measuring Depression. Arch General Psychiatry, 1961; 4: 53-6.

19. Riberto M, Miyazaki MH, Jucá SS, Sakamoto H, Pinto PPN, Batistella LR. Validação da Versão Brasileira da Medida de Independência Funcional. Acta Fisiat [Internet]. 2004 [cited 2016 Jul 12];11(2):72-6. Available from: http://dx.doi.org/10.5935/0104-7795.20040003

20. Carvalho NC. Dinâmicas para idosos: 125 jogos e brincadeiras adaptados. Rio de Janeiro: Vozes, 2014.

21. Oliveira CS, Costa SRR, Santos ICL, Lemos CES. Oficina de educação, memória, esquecimento e jogos lúdicos para a Terceira Idade. Rev Ciênc Ext [Internet]. 2012 [cited 2016 Jul 12];8(1):8-17. Available from: http://ojs.unesp.br/index.php/revista proex/ article/view/554/686

22. Almeida MHMD, Beger MLM, Watanabe HAW. Memory training for the elderly: a health promotion strategy. Interface Comunic Saúde Educ [Internet]. 2012 [cited 2016 Jul 12];11(22):271-80. Available from: http://www.scielo.br/pdf/icse/v11n22/07.pdf

23. Johari SM, Shahar S, Ng TP, Rajikan R. A preliminary randomized controlled trial of multifaceted educational intervention for mild cognitive impairment among elderly Malays in Kuala Lumpur. Int J Gerontol [Internet]. 2014 [cited 2016 Jul 12];8(2):74-80. Available from: http://dx.doi.org/10.1016/j.ijge.2013.07.002

24. Cruz TJP, Sá SPC, Lindolpho MC, Caldas CP. Cognitive stimulation for older people with Alzheimer's disease performed by the caregiver. Rev Bras Enferm [Internet]. 2015 [cited 2016 Jul 12];68(3):450-6. Available from: http://www.scielo.br/pdf/reben/v68n3/ en 0034-7167-reben-68-03-0510.pdf

25. Brucki SMD, Nitrini R. Cancellation task in very low educated people. Arch Clin Neuropsychol [Internet]. 2008 [cited 2016 Jul 12];23(2):139-47. Available from: http://dx.doi.org/10.1016/j.acn.2007.11.003

26. Ashendorf L, Jefferson AL, O'Connor MK, Chaisson C, Green RC, Stern RA. Trail Making Test errors in normal aging, mild cognitive impairment, and dementia. Arch Clin Neuropsychol [Internet]. 2008 [cited 2016 Jul 12];23(2):129-37. Available from: http://dx.doi.org/10.1016/j.acn.2007.11.005

27. Ordonez TN, Yassuda MS, Cachioni M. Elderly online: Effects of a digital inclusion program in cognitive performance. Arch Gerontol Geriatrics [Internet]. 2010 [cited 2016 Jul 12];53(2):216-19. Available from: http://dx.doi.org/10.1016/j.archger.2010.11.007

28. Marioni RE, Proust-Lima C, Amieva H, Brayne C, Matthews FE, Dartigues JF, Jacqmin-Gadda H. Social activity, cognitive decline and dementia risk: a 20-year prospective cohort study. BMC Public Health [Internet]. 2015 [cited 2016 Jul 12];15(1):1089. Available from: http://dx.doi.org/10.1186/s12889-015-2426-6

29. Bassoli S, Portella MR. Estratégias de atenção ao idoso: avaliação das oficinas de saúde desenvolvida em grupos de terceira idade no município de Passo Fundo - RS. Estud Interdiscip Envelhec [Internet]. 2004 [cited 2016 Jul 12];6:111-22. Available from: http:// www.seer.ufrgs.br/index.php/RevEnvelhecer/article/view/4744/2666

30. Mascarenhas NB, Melo CMM de, Fagundes NC. Produção do conhecimento sobre promoção da saúde e prática da enfermeira na Atenção Primária. Rev Bras Enferm [Internet]. 2012 [cited 2015 Dec 05];65(6):991-9. Available from: http://www.scielo.br/pdf/ reben/v65n6/a16v65n6.pdf

31. American Psychiatric Association. Diagnostic and Statistical Manual of Mental Disorders. Arlington, VA: American Psychiatric Association, 2013.

32. Carneiro RS, Falcone E, Clark C, Del Prette Z, Del Prette, A. Qualidade de vida, apoio social e depressão em idosos: relação com habilidades sociais. Psicol Reflex Crit [Internet]. 2007 [cited 2016 Jul 12];20(2):229-37. Available from: http://www.scielo.br/pdf/ prc/v20n2/a08v20n2.pdf

33. Rock PL, Roiser JP, Riedel WJ, Blackwell AD. Cognitive impairment in depression: a systematic review and meta-analysis. Psychol Med [Internet]. 2014 [cited 2016 Jul 12];44(10):2029-40. Available from: http://dx.doi.org/10.1017/S0033291713002535

34. Andrade LM, Sena ELS, Pinheiro GML, Meira EC, Lira LSSP. Políticas públicas para pessoas idosas no Brasil: uma revisão integrativa. Ciência Saúde Colet [Internet]. 2013 [cited 2016 Jul 12];18(12):3543-52. Available from: http://www.scielo.br/pdf/ csc/v18n12/a11v18n12.pdf

35. World Health Organization. World report in ageing and health. Summary. [Internet]. 2015. [cited 2016 Oct 15]. Available from: http://apps.who.int/iris/bitstream/10665/186468/1/WHO_FWC_ALC_15.01_eng.pdf?ua =1 